\title{
Фергана как FАТА? Центральная Азия после 2014 года - итоги и стратегические альтернативы
}

\author{
Тед Доннели *
}

\section{Введение}

После более десяти лет войны наиболее могущественные вооруженные силы вывели свои боевые части из Афганистана. Следуя разным стратегиям борьбы с повстанцами и террористами, оккупационные силы не имели успеха, но не были и побеждены. Эта сверхсила оставила после себя дружественное афганское правительство, достаточно хорошо подготовленные и хорошо экипированные войска безопасности. Так же после нее остались повстанцы, включая не только местных афганцев, но и исламистов из-за рубежа, чей боевой потенциал понес существенный урон, но не был уничтожен. Данная сверхсила продолжила свою поддержку союзникам правительства, обеспечивая финансирование, военную подготовку и техническое содействие, необходимые для подавления восстания. Однако, после двух лет, новые политические и экономические реалии заставили эту сверхсилу приостановить свою поддержку. Афганистан скатился к гражданской войне, в которой исламистские экстремисты взяли верх. В благодарность за поддержку новое исламистское правительство расплачивалось со своими иностранными джихадистскими союзниками безопасными убежищами, которые они использовали для тренировок и планирования атак против Соединенных Штатов, в числе прочих. Они также дестабилизировали соседей Афганистана, создавая условия, в которых вооруженный экстремизм процветает. К северу от Афганистана крайние экстремистские организации фокусировали свое внимание на Ферганскую долину, регион, который находится в самом сердце Центральной Азии и поделенный между тремя государствами. $^{1}$

Обрисованный выше сценарий начался в 1989 году и отступившая сверхсила, конечно, был Советский союз и его Красная армия. Проведение исторических параллелей может быть опасно ложным и другие значительные геостратегические события с 1989 по 1991 определенно имели влияние на постсоветский Афганистан и его соседей. ${ }^{2}$ Несмотря на это, уроки ухода Советского Союза из Афганистана мо-

В этой статье выражена точка зрения автора и она ни в коем случае не является официальной позицией Правительства, Министерства обороны или Армии США.

1 В контексте этой статьи понятия «Центральная Азия», «государства Центральной Азии» и «ГЦА» относятся только к бывшим советским республикам Узбекистан, Киргизская республика, Таджикистан, Казахстан и Туркменистан. Такова дефиниция этого региона и Министерства обороны.

2 Скоро после ухода Советского Союза из Афганистана в 1989 начался окончательный распад Советского Союза. Беспорядки и волнения в Восточно-Европейских государствах Варшавского договора сначала беспокоили Советский Союз, однако к декабрю 1991 сам 
гут быть полезны Соединенным Штатам, когда они в 2014 году окончательно передадут обязанности по обеспечению безопасности афганскому правительству. Как писал Б.Х. Лидл Харт, «целью войны является достижение более благоприятных условий мира». ${ }^{3}$ И все-таки, после тринадцати лет войны в Афганистане, Соединенные Штаты окажутся лицом к лицу с потенциальным пост-2014 «миром», при котором Центральная Азия будет менее стабильной, там будет больше террористов и она будет представлять большую угрозу Соединенным Штатам, чем это было 10 сентября 2001 года. По иронии судьбы (превратившейся в трагедию), война, которую начали, чтобы уничтожить убежища вооруженных экстремистов в Афганистане, может иметь в качестве непреднамеренного результата создание убежищ вооруженных экстремистов в Государствах Центральной Азии (ГЦА) непосредственно к северу от Афганистана. Это реалистический и даже вероятный будущий сценарий, частично потому, что стратеги США настаивали на рассмотрении стратегической проблемы через линзу чисто оперативных действий. Однако, это не является единственно возможным будущим и ни в коем случае неизбежным. Соответствующая стратегия может предотвратить такой исход. Анализ, представленный в этом эссе, обозначит наиболее вероятные последствия для государств Центральной Азии ухода в 2014 году США из Афганистана, с фокусом на Ферганскую долину стратегического центра гравитации этого региона. Далее будет оценены возможные варианты политики США и будет рекомендована пост-2014 стратегия.

\section{Значение Центральной Азии}

В 2001 году США вошли в Афганистан, естественно, не имея стратегии ухода. Более того, после десяти лет боев, им еще предстоит разработать стратегию для этого театра, которая относилась бы с подобающей серьезностью к огромному региону бывших советских республик к северу от Афганистана. С самого начала стратегия США для этого театра рассматривала Центральную Азию в чисто краткосрочной, оперативной перспективе. В 2001 году США нуждались в воздушных базах для транспорта войск и товаров, и для размещения истребителей, самолетов-топливозаправчиков и транспортных самолетов, и вели успешные переговоры о развертывании таких баз в Узбекистане и Киргизской республике. ${ }^{4}$ Позже, когда наземные ли-

Советский Союз распался. Помощь Советского Союза/Российской федерации Афганистану резко сократилась и вскоре после этого была прекращена.

3 B.H. Liddell Hart, Strategy (London: Faber \& Faber, 1954), 353.

4 Вскоре после 2001 Военно-Воздушные Силы США развернули две базы поддержки в Государствах Центральной Азии: одну в Харши-Канабаде в южном Узбекистане (известную как К2), и другую в международном аэропорту Манас Бишкека, Киргизская республика (сначала «Авиобаза Ганчи», названная в честь начальника противопожарной службы Нью-Йорка, погибшего 11 сентября 2001). К2 была основной базой, обеспечивающей поддержку операций в Афганистане, пока в 2005 году споры насчет арендной платы и обвинения США Узбекского правительства в нарушении прав человека в Андижане (район в Ферганской долине) не дали повод правительству Узбекистана изгнать США. С декабря 2005 база «Ганчи» (которой дали неуклюжее наименование «Транзитный центр в международном аэропорту Манас», или ТЦМАМ в июле 2009) была единственной базой под- 
нии снабжения через Пакистан оказались под нарастающим давлением, США развернули «Северную распределительную сеть», являющуюся комплексом наземных маршрутов снабжения из Европы в Афганистан, пересекающих несколько государств Центральной Азии. США поспешили заверить правительства стран Центральной Азии и нервированных соседних региональных сил - Россию и Китай, что заинтересованность США в этом регионе является только временной и существует только в контексте Операции «Несокрушимая свобода» (ОНС) в Афганистане. Это послание часто повторяли, пока «временное» присутствие США в регионе продолжалось, теперь уже более десяти лет. Таким образом, с 2001 года военные стратеги США рассматривали этот регион единственно как географическое и эпизодически как политическое препятствие операџиям - нечто, что нужно было пересекать по пути в Афганистан или из Афганистана. В соответствии с текущей стратегией, когда ОНС завершится, оперативная потребность в этом регионе отпадет и также отпадет заинтересованность в Центральной Азии. Текущую стратегию США в Центральной Азии можно подытожить как «делать все необходимое для сохранения наших баз и маршрутов снабжения открытыми, пока последний американский солдат не покинет Афганистан в 2014 году». ${ }^{5}$

Каким бы ни был важным для поддержки воюющих в ОНС такой подход, проблема с ним заключается в том, что он не учитывает стратегическое значение Центральной Азии самой по себе. Стратегический анализ региона показывает, что Афганистан и Центральная Азия неразрывно связаны - как в стратегическом, так и в оперативном отношении. Стратегический успех в Центральной Азии является стратегическим (а не только оперативным) для стратегического (а не только оперативного) успеха в Афганистане, и наоборот.

Определенно будет правомерным поставить вопрос, почему США должны опасаться перспективы нестабильности в Центральной Азии после 2014, или даже призрачной возможности учреждения исламского халифата в Фергане, имея в виду, что у США больше не будет оперативной потребности в транзите для обеспечения ОНС. Ответ имеет два аспекта.

Первый, стабильность в Центральной Азии является предварительным условием для стабильности и безопасности в пост-2014 Афганистане. Регион Федерально Управляемых Зон Племен (ФУЗП) в Пакистане является полезным и подходящим примером на этот счет. Регион ФУЗП представляет большое неуправляемое пространство и служит убежищем для многочисленных вооруженных экстремистских организаций, многие из которых проводят операции в Афганистане. Эти группы являются существенным источником нынешней нестабильности в Афганистане и

держки в Центральной Азии и потому ее значение существенно увеличилось. За свои усилия правительства стран Центральной Азии получали чуточку больше помощи от США, больше высокопоставленных визитов (в основном военных) и изредка передышку от критики за состояние прав человека и демократии.

5 James N. Mattis, "U.S. Central Command Posture Statement," presented before the Senate Armed Services Committee on 1 March 2011; доступно на: http://www.centcom.mil/en/aboutcentcom/posture-statement. 
останутся таковым и после 2014 года. Аналогичный регион к северу (и который даже формально не будет дружественным США) был бы опустошительным для будущего Афганистана, так как страна окажется окруженной дестабилизирующими режимами. В таком окружении немыслимо, чтобы Афганистан смог уцелеть как стабильное, независимое государство, которое не покровительствует международному вооруженному экстремизму.

Второй, и может быть более важный в стратегической перспективе аспект, государства Центральной Азии могут потенциально стать тем, чем была Турция когдато и тем, чем Египет, Ливия, Ирак и Сирия никогда не будут - умеренными, светскими, с преобладающим мусульманским населением государствами, которые относятся не враждебно (а может быть даже и дружественно) к интересам США. При правильной стратегии такой исход достижим и без существенного расходования ресурсов. Государства Центральной Азии не требуют дорогостоящих (и бесплодных) усилий для формирования нации, также они не требуют неуклюжих информационных кампаний об опасностях экстремизма и достоинствах секуляризма. Однако, им нужна скромная помощь для поддержки этих характеристик.

В то время как стратегия для театра пост-2014 обязательно должна быть сфокусирована на Афганистане и Пакистане, она не должна пренебрегать государствами на севере Центральной Азии. Как было отмечено выше, Афганистан и Центральная Азия стратегически связаны. Более того, комплекс проблем Центральной Азии совсем не настолько неразрешим, как комплекс вызовов перед Пакистаном. Вполне возможно до 2014 разработать и начать применять стратегию для этого театра, которая продвигала бы интересы США путем защиты стратегического центра тяжести Центральной Азии, Ферганской долины. Это создаст условия, необходимые для обеспечения стратегического успеха в Афганистане. И что важнее всего, во времена урезанных бюджетов и ограничения международных ангажементов США, это не будет ни финансово дорогостоящей, ни требующей больших человеческих ресурсов стратегией.

\section{Предположения относительно ухода США из Афганистана}

Анализ, представленный в этой работе, основывается на нескольких предположениях. Первое, военное присутствие США закончится в декабре 2014 года, как и было заявлено, с передачей ответственности по поддержанию безопасности афганским силам. ${ }^{6}$ В то время как лидеры НАТО декларировали, что вывод войск будет «основан на выполнении определенных условий, а не подстегиваться календарем», ${ }^{7}$

6 «Боевые части» в этом контексте относятся к большим конвенциональным формированиям. Остается возможность, даже вероятность, что Силы для специальных операций США останутся действовать в Афганистане, и что США продолжат использование ударов беспилотными летательными аппаратами против дорогостоящих целей.

7 NATO Public Diplomacy Division, Press Release 155, "Lisbon Summit Declaration Issued by the Heads of State and Government in the meeting of the North Atlantic Council" (Lisbon, 20 November 2010), 2; доступно на www.nato.int/cps/en/natolive/official_texts_68828.htm?mode =pressrelease. 
президент Обама заявил, что боевые операции будут завершены к 2014 году. ${ }^{8}$ В самом деле, вывод «пиковых» войск США уже начался. Если пример Ирака вообще является показательным, вряд ли на местном уровне будет какой бы то ни было политической воли продолжить военное присутствие США после 2014, и может быть даже оказано давление, чтобы вскоре после этого были выведены и инструкторы. Какой бы ни была конечная дата, когда-нибудь она наступит, и стратегия США должна рассматривать Афганистан, в котором не будут присутствовать боевые части США и афганские силы несут полную ответственность за безопасность страны.

Второе предположение состоит в том, что помощь США, и военная и на развитие, не может и не будет на нынешнем уровне. И это не просто результат бюджетных реалий в США, но также и следствие усталости и ослабевания интереса американского населения и его выборных лидеров. Пост-2014 стратегия должна основываться на предположении, что на деятельность США в регионе будут выделяться меньшие финансовые и человеческие ресурсы. Принимая первые два предположения, было бы логично предполагать, что пост-2014 правительство Афганистана и его силы безопасности не будут контролировать 100 процентов его территории.

И последнее, не похоже, что основные региональные силы, Россия и Китай, будут поддерживать какую бы то ни было стратегию США, которая включает продолжение американского присутствия и его существенное влияние в регионе. Пост1991 тенденция активного противодействия физическому присутствию, вероятно, продолжится, как это и было последние двадцать лет, несмотря ни на какие прозрения в душах лидеров и нажатие «Reset» клавишей.

\section{Последствия ухода США для государств Центральной Азии}

В свете этих четырех предположений, каков будет эффект ухода США на государства Центральной Азии после 2014 года? Чтобы заглянуть вперед, было бы полезно ненадолго вернуться к советскому опыту, упомянутому выше. Вывод советских войск из Афганистана в 1989 году создал вакуум власти в регионе и привел к гражданской войне в этой стране. Коллапс самого СССР через два года привел к прекращению советской помощи Афганистану, подготовки и экипированию афганских сил безопасности. Талибаны выиграли гражданскую войну и в свою очередь предоставили свою территорию транснациональным организациям единомышленников, включая, естественно, как хорошо известную сеть Осамы Бен Ладена - Ал Кайда, так и менее известные вооруженные экстремистские организации как Исламское движение Узбекистана (ИДУ), которое стремится к учреждению Исламского халифата в Центральной Азии с центром в Ферганской долине. ${ }^{9}$

8 Barack Obama, Press Conference by U.S. President at the North Atlantic Meeting at the level of Heads of State and Government (Lisbon, 20 November 2010); доступно на www.nato.int/cps/ en/natolive/official_texts_68828.htm?mode=pressrelease.

9 U.S. Department of State, Office of the Coordinator for Counterterrorism, Country Reports on Terrorism 2010 (Washington, D.C.: State Department, August 2011). Государственный де- 
На севере, распад Советского Союза и последовавший вывод почти всех сил, обеспечивающих безопасность, из Центральной Азии, вскоре после этого создали другой вакуум власти. Центральная советская власть была заменена несколькими новыми, слабыми государствами, которые боролись за внутреннюю консолидацию власти и создавали свои собственные силы безопасности из остатков того, что оставили после себя Советы. ИДУ и связанные с ним группы процветали в этом окружении, начав нападение на правительство Узбекистана в 1999 году. ИДУ также попыталось одним ударом установить Центрально-азиатский халифат, нападая на Кир ᄀгизскую республику со своих баз в Узбекистане и Таджикистане, успешно захватив и на короткое время удержав территорию во время «Баткенских событий» в 1990-2000..$^{10}$

Хотя ИДУ в конечном итоге не достигло успеха в этих тактических столкновениях, оно не было побеждено стратегически и на самом деле приобрело значительный престиж за счет правительств Узбекистана и Киргизской республики. ${ }^{11} 11$ сентября 2001 года можно было утверждать, что ИДУ располагало стратегическим импульсом в Ферганской долине, несмотря на его тактические поражения.

партамент США обозначил две ценрально-азиатские организации как «Иностранные террористические организации»: Исламское движение Узбекистана (ИДУ) и Союз исламского джихада (СИД), отколовшуюся от ИДУ группу. Активной в регионе является и Хизб-ут-Тахрир (ХуТ), якобы невооруженная группа, которая стремится к учреждению исламского халифата в Центральной Азии. Государственный департамент США не считает ХуТ иностранной террористической организацией, но она запрещена во всех государствах Центральной Азии и в России. Так как ИДУ является старейшей, наиболее эффективной и наиболее опасной вооруженной экстремистской организацией в Центральной Азии, то с целью упрощения этот анализ относится в основном к ИДУ. Однако, последствия ухода США из Афганистана будут выгодны всем исламистским экстремистским группам в Центральной Азии, и рекомендованный вариант политики США применим и к ним.

10 В 1999 ИДУ начало вооруженное нападение на Баткенский район (тогда являющимся частью Ошской области) с целью отделить его от Киргизской республики и создать зародышный халифат. Баткен был выбран из-за его удаленности от области, близости к Ферганской долине, слабого контроля со стороны центральных киргизских властей и слабости киргизских сил безопасности. ИДУ успешно захватило нескольких деревень и нанесло серьезные потери киргизским силам прежде, чем было отброшено киргизским контранаступлением. Баткенская область является беднейшим, наиболее религиозным и наиболее удаленным районом Киргизской республики. Это узкий горный регион, граничащий с Ферганской долиной на юге. Постсоветская политическая география изолировала его от остальной части Киргизской республики даже больше, чем его физическая география. Большинство советских дорог проходит через Ферганскую долину, что означает, что для того чтобы проехать от областного центра Ошской области к большинству поселков в Баткене, надо пересекать Узбекистан. Ввиду плохих отношений между двумя странами, передвижение вооруженных сил через узбекскую территорию (т.е. по прямым маршрутам) в целом невозможно.

11 Узбекская реакция была жесткой, репрессивной и непропорциональной. Киргизская реакция показала некомпетентность и небоеготовность киргизских сил безопасности. 
Операция «Несокрушимая свобода» уничтожила наступательный импульс ИДУ и нанесла ему тяжелое оперативное поражение. Не являясь специальной целью для ОНС, бойцы ИДУ, проводящие подготовку и планирование операций почувствовали, что их убежища в Афганистане находятся под ударом. ИДУ понесло множество потерь от атак США и Коалиции и когда режим талибанов был свергнут, они также потеряли свои надежные убежища. ${ }^{12}$ Активность ИДУ в Центральной Азии резко упала вследствие начального успеха США и Коалиции в Афганистане в 2001 и 2002 годах, и организация перебазировала свои тылы в Пакистан, гораздо дальше от их целей в Ферганской долине и с вооруженными силами США в Афганистане между ними.

Как отмечалось выше, исторические параллели часто несовершенны, эта в том числе. Ясно, что распад СССР, последовавший всего через два года после вывода советских войск из Афганистана, был значительным фактором в обеспечении успеха талибанов и ИДУ - также фактор, который нельзя переоценить. Однако трудно представить себе пост-2014 сценарий, в котором афганские силы безопасности будут контролировать всю афганскую территорию и сделают ее негостеприимной для иностранных вооруженных экстремистских организаций, таких как ИДУ. Весьма похоже, что вывод американских войск создаст другой вакуум власти и выльется в другой вид борьбы за власть.

Итак, где Центральная Азия в этом сценарии? И снова советский опыт годится только до этого момента. Государства Центральной Азии независимы более двадцати лет и за это время создали свое правление и силы безопасности. В отличие от непосредственного постсоветского периода 90-ых, им не придется воевать с повстанцами, пытаясь возродить собственные нации из хаоса. Трудно, однако, представить себе будущий сценарий, в котором базированные в Фергане террористические группы не были бы воодушевлены, укреплены и расширены вследствие ухода США в 2014. Очевидно, вакуум, который возникнет с уходом США из региона, не будет таким существенным, как после ухода Советов в 1991 - как было отмечено, присутствие США в Центральной Азии было минимальным, американская помощь нерегулярной и интерес США краткосрочным и оперативным.

И все-таки, уход США будет иметь существенные последствия для государств Центральной Азии - Узбекистан, Таджикистан и Киргизскую республику. ${ }^{13}$ Хотя каждое из этих государств отметило двадцатилетие своей независимости, все они остаются слабыми государствами. В декабре 2011 Киргизская республика инаугурировала демократически избранного президента, это первый мирный переход власти в постсоветской Центральной Азии. И все-таки в этой молодой демократии имеется ощутимое этническое напряжение на юге и чувствуется слабость экономики на всей территории. В Узбекистане сильный человек с советских времен, Ис-

12 Richard Weitz, "Storm Clouds over Central Asia: Revival of the Islamic Movement of Uzbekistan (IMU)?," Studies in Conflict and Terrorism 27:66 (2004): 507.

13 Непосредственное влияние на Казахстан и Туркменистан, похоже, будет менее значительно. Влияние на эти страны проявится только при «худшем сценарии», который будет обсуждаться ниже. 
лам Карымов, стар и болен, и по-видимому, план передачи власти отсутствует, что делает эту страну гораздо менее устойчивой, чем она кажется на первый взгляд. Таджикистану только еще предстоит восстанавливаться после опустошительной гражданской войны, которую он пережил в 90-ых после ухода Советов, и таджикские вооруженные силы понесли значительные потери в войне с повстанцами в 2010.

В Центральной Азии последствия ухода США сильнее всего скажутся на районе Ферганской долины. Как было отмечено выше, Ферганская долина является стратегическим центром тяжести в Центральной Азии, благодаря своему центральному географическому положению, исключительно плодородной почве, плотности населения, сильного религиозного влияния, нестабильности и отсутствия управления со стороны центральной власти. ${ }^{14}$ Ее территория разделена между тремя государствами: Узбекистану принадлежит большая часть плодородных низин, Киргизской республике - предгорье и некоторые из главных населенных пунктов, а Таджикистан контролирует подходы к долине. Международные границы не везде следуют традиционным линиям разделения этнических групп, добавляя еще один дестабилизирующий фактор. Хотя правительства Таджикистана и Киргизской республики находятся в общем-то в хороших отношениях, в то же время существует множество местных споров в граничных областях Ферганской долины. Правительства Узбекистана и Киргизской республики находятся в плохих отношениях, что существенно затрудняет региональное сотрудничество. Центральное положение долины, этническое разнообразие и общий политический статус гарантируют, что любая нестабильность в Ферганской долине коснется как минимум этих трех государств. И выражение «Что происходит в Ферганской долине, происходит и в Центральной Азии» не клише и не сильное упрощение.

\section{Потенц̧иальные пост-2014 сценарии для Ферганской долиньл}

Для Ферганской долины возможны три сценария будущего. В худшем сценарии домино Ферганы начнет падать сразу после 2014. После ухода США из Афганистана ИДУ начнет полномасштабное нападение на долину. Таджикистан, Узбекистан и Киргизская республика превратятся в исламистские государства в течении двух лет. Этот сценарий как мрачен, так и маловероятен. Даже в период 1999-2000 гораздо более слабые правительства стран Центральной Азии были в состоянии отбить нападения ИДУ. Однако, этот вариант нельзя полностью сбрасывать со счетов. События в Киргизской республике с апреля по июнь 2010 показали, насколько быстро кажущееся «сильным» правительство может пасть при ограниченном давлении, и насколько быстро силы безопасности могут потерять контроль, при этом в

14 U.S. Joint Chiefs of Staff, Joint Operation Planning, Joint Publication 5-0 (Washington, DC: U.S. Joint Chiefs of Staff, 11 August 2011). Совместная публикация 5-0 дефинирует «центр тяжести» как «источник мощи, который обеспечивает духовную или физическую силу, свободу действий или волю к действию». Это то, что Клаузевиц называл «средоточием всей мощи и движения, от которого зависит все ... точка, на которую надо направить всю нашу энергию». 
полном объеме. К тому же, таджикские вооруженные силы понесли существенные тактические поражения, воюя против движения Талибан в 2010 и $2011 .{ }^{15}$ Несмотря на все это, в ближайшем будущем захват исламистами Центральной Азии будет возможен только если афганские вооруженные силы распадутся быстро и зрелищно в пост-2014 периоде.

Еще менее вероятным является наиболее благоприятный сценарий, при котором стабильность в Фергане укрепляется после ухода США из Афганистана. При этом исходе сфокусированные на Фергане экстремистские группы увядают, распадаются или присоединяются к ненасильственному политическому процессу. Вооруженные экстремисты становятся редкостью или нонсенсом с несущественным влиянием на региональную стабильность. Некоторые критики (местные и международные) политики США в Центральной Азии с давних пор утверждают, что присутствие США является действительным источником нестабильности в этом регионе, обеспечивая raison d'être вооруженным экстремистским группам. ${ }^{16}$ Предположительно, согласно этой точке зрения, устранение источника (т.е. США) устранит, или в крайнем случае ослабит проблему.

Это предположение, однако, игнорирует несколько ключевых факторов, а именно то, что ИДУ и подобные ему в значительной степени предшествует серьезному интересу США (не говоря уже о присутствии) в регионе Центральной Азии, и то, что активность ИДУ уменьшилась только тогда, когда США уничтожили их афганские убежища. Более того, есть недавний подтверждающий пример, что вооруженная экстремистская активность в Узбекистане не уменьшилась, когда войска США были изгнаны с авиабазы Харши-Канабад в 2005. К тому же некоторые выдающиеся региональные лидеры публично выразили свою озабоченность тем, что вывод войск США из Афганистана приведет к нестабильности в Центральной Азии. ${ }^{17}$ (Мнение, которое часто озвучивается в частных разговорах региональными лидерами и связанными с обороной и безопасностью официальными лицами. ${ }^{18}$ )

Наиболее вероятным исходом пост-2014 является тот, при котором Ферганская долина все более будет похожа на регион Федерально управляемых зон племен (ФУЗП; Federally Administered Tribal Areas - FATA) в Пакистане. Как и ФУЗП, будущая Ферганская долина будет представлять неконтролируемое пространство, ко-

15 U.S. Department of State, Country Reports on Terrorism 2010, 125-27.

16 Эти заключения выведены из многочисленных формальных и неформальных дискуссий автора с официальными лицами, связанными с обороной и безопасностью, и с гражданами Киргизской республики с августа 2009 по июнь 2011, и в Европейском центре исследований в области обороны «Джордж С. Маршалл» с июля 2006 по июль 2009 г.

17 Уходящий президент Киргизской республики Роза Отынбаева выразила эту озабоченность публично. Смотри Rick Gladstone, "Kyrgyzstan Sees Instability at End of Afghan Mission,” New York Times (26 November 2011). Так же высказались Посол России в НАТО, Генеральный секретарь Организации договора о коллективной безопасности и другие. See Joshua Kucera, "Why Russia Fears U.S. Afghan Plan," The Diplomat (18 October 2011).

18 В ходе официального и неофициального общения автора и чиновников, связанных с безопасностью, и гражданскими лицами из региона. 
торое может служить убежищем, питомником и сценой для вооруженных экстремистских организаций и милиций. ИДУ и другие экстремистские группы смогут использовать это убежище, так же как и реформирование своего тыла в Афганистане, на увеличение повстанческого давления на светские правительства центрально-азиатских государств.

И в самом деле, есть четкие признаки, что этот исход начал обозначаться. Как обсуждалось выше, ИДУ получило серьезный удар при вводе американских войск в Афганистан. Однако, с ослабеванием интереса США к Афганистану и смещением фокуса внимания к другим регионам, ИДУ постепенно восстановило свою организацию. Когда коалиционные силы ограничили свои операции только на севере и востоке страны, ИДУ нашло новые убежища на юге. Операции в Ферганской долине возобновились в Киргизской республике (Ош, Узген, Джелалабад и Бишкек) и в Таджикистане в 2009 и 2010. Эта тенденция продолжается и в настоящее время, примером чему является недавнее предотвращение планированного террористического удара в Киргизской республике в октябре 2011.

Расширение зоны американских операций на юге Афганистана в 2007 снова увеличило давление на ИДУ и в процессе почти ироническим образом усилило присутствие ИДУ и связанных с ним групп в Ферганской долине, так как они сбежали с территорий интенсивной военной активности США на юге. Действительно, увеличенное присутствие бойцов ИДУ в Фергане приводится как подтверждение успеха в Афганистане. Когда коалиционные войска начали выталкивать повстанцев из до того непотревоженных областей на юге и западе Афганистана, они «выжали губку» и лишняя «влага» (вооруженные экстремисты в этой метафоре) осела в Фергане. Киргизские силы безопасности провели несколько успешных операций против клеток вооруженных экстремистов в городах Ферганской долины Ош и Джелалабад летом 2009 и снова осенью 2010, и с меньшим успехом на юго-западе Баткенской области осенью 2009. Таджикские силы безопасности справились хуже, потеряв значительную часть личного состава своего лучшего антитеррористического подразделения во время экстремистских действий осенью 2010. Эти события определенно привлекли внимание верхнего эшелона военных и гражданских официальных лиц стран Центральной Азии.

Очевидно, террористические действия, направленные на Ферганскую долину, имеют устойчивую тенденцию расширения с 2007 года. Как мы видели в контексте новейшей истории, базированные в Фергане террористические группы увеличивают свою активность и имеют больший успех, когда существует вакуум власти или Афганистаном правит происламистское правительство. Легко представить себе сценарий будущего, в котором ИДУ и его террористические побратимы становятся сильнее и расширяют свою деятельность после ухода США из Афганистана. Основное отличие между нынешней Ферганой и будущей в том, что после 2014 ИДУ и связанные с ним движения не будут испытывать военное давление на их Афганские тылы, с которым они имеют дело сейчас.

B смысле намерений, этот «Фергана как FATA» сценарий не отличается существенно от стратегической цели ИДУ основать центрально-азиатский исламский ха- 
лифат с центром в Ферганской долине. В самом деле, этот исход продолжает пост2007 тенденцию увеличения активности как внутри, так и вокруг этого субрегиона. Разница, однако, будет в степени и значимости. Без давления США на их афганские и пакистанские убежища, вооруженные экстремистские организации Центральной Азии будут в состоянии выделить больше ресурсов Ферганской долине и вероятнее всего сосредоточат свои усилия там.

Далее, повстанческие группы изменились с 1990 года. Американские военные стали более умными, выносливыми и умелыми после десяти лет войны, так же как и экстремистские организации Центральной Азии. У боевиков ИДУ так же было более десяти лет на усовершенствование их тактики, техники и процедур в боях против США, НАТО и афганских сил. Эти закаленные в боях повстанцы представляют собой большую угрозу для относительно неопытных центрально-азиатских сил безопасности, чем были их предшественники в 1990-ых. Далее, после 2014 вооруженные экстремистские группы будут продолжать получать свою прибыль с налаженной торговли афганскими наркотиками, чего не было в 1990-ых. Не будет преувеличением сказать, что после ухода США из Афганистана стратегический импульс в Ферганской долине снова сместится к исламистским экстремистским группам.

\section{Варианты политики США}

У Соединенных Штатов три широкоформатных варианта политики в Центральной Азии после 2014, которые будут обсуждаться ниже.

Вариант 1: Полный вывод военных сил и пересмотр приоритетов. В соответствии с нынешней стратегией, после 2014 Центральная Азия вернется к своему статусу до сентября 2001 - а именно, регион низкого для США приоритета, где будут расходоваться минимальные усилия и ресурсы. В этом варианте, военные США выводят свои силы, закрывают свои сооружения и переключаются на низкий уровень военных ангажементов. Военные из стран Центральной Азии будут время от времени получать приглашения на международные конференции и продолжат принимать участие в организованными на контрактной основе компьютерных учениях, но по большому счету Министерство обороны оставит этот регион позади, относясь к нему как к некоему «Острову др. Моро», на котором Государственный департамент мог бы проводить эксперименты в области демократии и прав человека.

Полный вывод сил мог бы иметь свои преимущества. Первое, присутствие США всегда было спорным, как внутри региона, так и для таких скептически настроенных соседей и региональных факторов, как Россия и Китай. Как минимум, устранение военного присутствия США исключит любимую тему российских, спонсорированных государством, отрицательно настроенных средств массовой информации, что в свою очередь ограничит региональное недовольство. При правильной реализации этот вариант может обернуться крупным информационным успехом для США.

Между тем, освобожденные от груза гарантированного стратегического доступа, дипломаты США смогут сфокусироваться на другие, невоенные вопросы, 
включая стабильность в Ферганской долине. Однако полный уход и снижение приоритета региона оставит американским дипломатам мало ресурсов и еще меньше влияния, которые можно использовать на укрепление стабильности в Фергане. К тому же, закрытие Транзитного центра в Манасе будет иметь существенное, прямое и незамедлительное негативное экономическое влияние на Киргизскую республику, включая потерю рабочих мест, арендной платы и закупок местных продуктов. ${ }^{19}$ Меньший, вторичный эффект почувствуется в Узбекистане и Таджикистане. Почти одновременное уменьшение иностранной помощи США создаст большой дестабилизирующий экономический вакуум.

В военном отношении, этот вариант лишит центрально-азиатские силы безопасности возможности успешной подготовки и оснащения, которые сейчас обеспечиваются в результате высокого приоритета региона и его оперативного значения для тех, кто определяет политику США. Силы безопасности будут неподготовлены воевать с возродившимися, закаленными в боях, вооруженными экстремистскими группами в Ферганской долине, как раз тогда, когда эта подготовка наиболее необходима.

Подвариант Варианта 1 мог бы устранить некоторые из его недостатков путем международных действий. В «Варианте 1а» роль США была бы такой же, как и в Варианте 1, но США будут работать с другими региональными силами и организациями, чтобы заполнить вакуум власти. Отходу США будет предшествовать сильное дипломатическое давление с упором на то, чтобы убедить Россию, Китай и Индию работать на двухсторонней основе с правительствами Центральной Азии для стабилизации Ферганской долины, подобно тому как русские войска много лет помогают в охране южной границы Таджикистана. Дополнительно США могут попытаться действовать через региональные организации, такие как Шанхайская организация сотрудничества (ШОС) и Организация договора о коллективной безопасности (ОДКБ), которые пользуются уважением в регионе.

Вариант 1а в какой-то мере апеллирует к тем, кто определяет политику США. Он является прежде всего и больше всего региональным, многосторонним решением региональной проблемы, причем таким, что будет требовать минимум американских ресурсов. Он обеспечит форум для расширения сотрудничества с Россией в соответствии с политикой «reset»-а отношений. Однако, при близком рассмотрении, Вариант 1а выглядит нереалистичным. На первом месте, на двухсторонней основе, Россия, Китай и Индия имеют разные и часто конкурирующие интересы в Центральной Азии. Хотя региональная стабильность в целом должна быть в интересах всех сторон, Китай в основном сфокусирован на своих экономических интересах в регионе, и не желает играть никакой роли в региональной стабильности и безопасности. Россия в свою очередь посылает смешанные сигналы, послав в 2011 группу из сорока паравоенных советников помогать Киргизской республике в охране гра-

19 Страница Посольства Соединенных Штатов в Бишкеке, Киргизская республика, на http://bishkek.usembassy.gov/tc_recent_contributions.html. 
ниц, но также и отказав отчаянной просьбе Киргизии послать миротворцев во время этнического насилия при «Ошских событиях» в июне 2010.

Тогда как США рассматривает региональную стабильность в контексте сильных независимых государств, изнутри уважающих права человека, и внешне проживающих в мире со своими соседями, не ясно, разделяет ли Российская федерация это определение. С Китаем, уже доминирующим экономически в регионе (тенденция, которая будет продолжаться и даже усиливаться), основное значение России заключается в ее качестве как гаранта безопасности. Россия в меньшей степени заинтересована в обеспечении существования сильных независимых государств, способных охранять свои собственные границы и свою собственную территорию. В то время как Россия беспокоится из-за исламистов на своей южной границе, она также имеет интерес в зависимости государств Центральной Азии от ее политики при обеспечении их безопасности.

Дополнительно, Россия и Китай в целом противопоставляют себя политике США в Центральной Азии последние десять лет, часто весьма рьяно. Тогда как оба государства с удовольствием пытаются заполнить вакуум влияния, непохоже, что они сразу же согласятся лить воду на мельницу интересов США. Более того, когда США уйдут из региона, они потеряют большую часть сферы влияния не только на правительства государств Центральной Азии, но также и на соседние региональные силы. Дипломаты США будут располагать исключительно ограниченным инструментариумом, который можно использовать, чтобы убедить Россию и Китай активно поддерживать интересы США в Ферганской долине.

В плане многосторонних отношений, так как ШОС формально призвала к прекращению присутствия США в Центральной Азии, ${ }^{20}$ снова не похоже, что эта организация согласится работать в направлении интересов США в регионе. Между тем, ни ШОС, ни ОДКБ не доказали свою эффективность, кроме как на уровне риторики. Таким образом, привлекательный на первый взгляд, Вариант 1а попадает в категорию «слишком хорошо, чтобы было правдой», так как весьма маловероятно, что он осуществится. Опираясь почти всецело на Россию, Китай и организации, доминированные этими государствами, этот вариант существенно увеличивает риск того, что желаемая стратегия США провалится и национальные интересы не будут реализованы.

Вариант 2: Пост - 11 сентября 2001 статус-кво. Этот вариант политики противоположен Варианту 1. В этом варианте предполагается, что в Центральной Азии к 2015 году и после мало что изменится. Регион останется с высоким приоритетом - хотя, с устранением оправдания оперативного военного участия в Афганистане, политика США наконец подтвердит и рассмотрит стратегическое значение Центральной Азии самой по себе. США будут поддерживать существенное военное присутствие в регионе, в основном в Транзитном центре в международном аэро-

${ }^{20}$ Shanghai Cooperation Organization, "Declaration by the Heads of the Member States of the SCO," SCO Annual Summit, Astana, Kazakhstan, 5 July 2005; доступно на www.eurasianhome.org/doc_files/declaration_sco.doc. 
порту Манаса (ТЦМАМ) в Киргизской республике. Несмотря на недавние заявления новоизбранного президента Киргизской республики Алмазбека Атамбаева, что воздушная база будет закрыта, вариант с сохранением статус-кво жизнеспособен. США могут договориться о продлении соглашения о ТЦМАМ, и правительство Киргизской республики будет более восприимчивым, если будут предложены справедливые условия. ${ }^{21}$

Конечно, необходимость транспортировать большое количество личного состава и тысячи тонн грузов в Афганистан отпадет и Транзитному центру понадобятся новая миссия, переструктурирование и новое имя. Это «новое» военное сооружение США надо будет преобразовать как платформу региональной поддержки сотрудничества США и его союзников в области безопасности, публичной дипломатии и антитеррористической деятельности. Существующие программы сотрудничества (укрепление институтов обороны, реформирование сектора безопасности, обмен военными делегациями, ограниченная подготовка и оснащение сил безопасности) будут продолжаться, но с большим региональным фокусом. В этом варианте Министерство обороны останется ведущей агенцией участия США и военный элемент будет доминирующим, как это было после событий 9/11. Однако, дипломатические, экономические и информационные виды деятельности также продолжатся.

Вариант с сохранением статус-кво располагает преимуществом поддержки сильного присутствия США (хотя и преимущественно военного) в регионе после 2014. Это присутствие не только обеспечит необходимые ресурсы для поддержания текущего уровня помощи, но также продемонстрирует готовность продолжать обвязанность США с этим регионом, независимо от операций в Афганистане. Существенное присутствие США также продолжит обеспечение значимых экономических выгод, и его сохранение предотвратит тяжелые краткосрочные, потенциально де $\neg$ стабилизирующие экономические последствия. ${ }^{22}$

Однако, выгоды от поддержания большого военного сооружения США в регионе после 2014 значительно перевешиваются его негативами, в основном в плане стратегической коммуникации и дипломатии. С тех пор как было установлено при-

21 Транзитный центр обеспечивает существенные прямые (арендная плата) и косвенные вклады (расширенная помощь, местная торговля, зарплата местного персонала) в Киргизскую экономику. Присутствие США обеспечивает и полезный инструмент в отношениях с Россией, позволяя также добиваться лучших концессий. Предшествовавшие требования к США освободить ТЦМАМ были просто начальной позицией в последовавших переговорах. В контексте политики Варианта 2, США могли бы представить Киргизскому правительству сохранение ТЦМАМ как необходимой платформы для американской помощи. Если пакет компенсаций будет включать строительство второй взлетно-посадочной полосы и продолжение оказывания американской помощи для превращения Центра в международный гражданский грузовой терминал (оба проекта являются давними киргизскими целями, второй уже частично финансирован США), вероятно соглашение будет достигнуто.

22 Страница Посольства США в Бишкеке, Киргизская республика, на http://bishkek.usembassy.gov/tc_recent_contributions.html. 
сутствие США на региональных авиабазах, Штаты неоднократно уверяли местные правительства и озабоченных соседей, Россию и Китай, публично и частным образом, что Транзитный центр в Манасе является только временным сооружением для поддержки военных операций Коалиции в Афганистане. Любая попытка продолжить использование ТЦМАМ дольше, чем того требуется для операции «Несокрушимая свобода», будет иметь опустошительный эффект на имидж и репутацию США в Центральной Азии. Она только подтвердит региональные теории конспирации и давние подозрения России о желании США установить постоянное присутствие, и будет использована как Россией, так и ИДУ. Хотя правительства в регионе можно будет убедить, что в их интересах будет принятие ими на своей территории военного сооружения США, их народы вряд ли примут такой аргумент.

Более того, необходимость поддерживать военные сооружения в регионе требовала большого расхода дипломатических усилий США с 2001 и затеняла почти все невоенные ангажементы и оказываемую помощь. ${ }^{23}$ Продолжение этой потребности гарантировало бы, что военное присутствие США будет доминировать во всех будущих важных диалогах и мешать дипломатам, экспертам и военным фокусировать свою энергию и усилия на проблемах Ферганской долины и стабильности в регионе.

В итоге, вариант статус-кво не может обеспечить достижение стратегических целей в этом театре действий. Более чем десять лет доминирующе-военной региональной политики не принесли стабильности в Ферганской долине. Успешная для Центральной Азии пост-2014 стратегия не может просто продолжать фокусироваться на оперативных целях, воплощенных в ее основном артефакте, Транзитном центре в Манасе, и ожидать достижения долгосрочного принятия в регионе.

Вариант 3: Накопленный опыт и лучшие практики. Есть много чему поучиться от взаимодействия США и Центральной Азии в течении последних десяти лет. Этот вариант политики требует, чтобы США сделали свои выводы из прошедшей декады, мысля стратегически, инкорпорируя лучшие практики и элиминируя неуспешные или вредные подходы прошлого.

Первый вывод состоит в том, что думать и действовать надо на стратегическом уровне, а не на оперативном. Чтобы добиться успеха на долгий срок, США должны использовать долгосрочный подход, который требует на первом месте признания стратегического значения региона, отдельно от оперативных соображений, связанных с Афганистаном. В конечном итоге, Ферганская долина, как стратегический центр тяжести региона, должна быть центральной для любой будущей стратегии. Стабилизация Ферганской долины должна быть основной целью США (в отличие от цели «поддерживать наши базы и маршруты перевозок»).

Сделав стабильную Ферганскую долину основной целью, политика США будет соответствовать основной цели правительств в регионе. Это облегчит реализацию

23 Значительное количество времени и усилий дипломатов (и на высшем, и на рабочем уровне) в Центральной Азии после 11 сентября 2001 было сфокусировано на проблемы обеспечения баз и транзита. 
второго вывода, а именно, что ведущая роль должна принадлежать правительствам в регионе, применять партнерский подход, а не подход - хозяин (они) и квартиросъемщик (мы), которому следовали в течении последних десяти лет. И это не просто семантика. Выплата региональным правительствам «аренды» за пользование их территорией, независимо, являются ли эти выплаты прямой платой за базы, или это сборы за воздушный или наземный транзит, краткосрочная природа интересов и обязательств США только поощряет крайние требования региональных правительств увеличивать арендную плату. И США и правительства стран Центральной Азии разделяют общий интерес в стабильной Ферганской долине. Следовательно, стратегия тоже должна быть общей, от этапа разработки до применения.

Однако, Россия и Китай также являются частью этого региона, и ШОС и ОДКБ, хотя и неэффективны, пользуются авторитетом в регионе. Следовательно, США должны защищать и продвигать участие России, Китая, ШОС и ОДКБ в региональной стратегии. Это не противоречит выше упомянутым утверждениям - что Россия и Китай имеют конкурирующие интересы и маловероятно, что активно будут участвовать в стратегии, включающей США, даже если правительства стран региона будут ведущими в применении этой стратегии. Остается верным то, что США не должны ожидать существенной поддержки со стороны России или Китая и даже могут встретить активное противодействие (как и в Варианте 2). Скорее, позиция регионального участия относится в основном к политическим, дипломатическим и информационным задачам.

Что касается информации и общественных коммуникаций, третий вывод заключается в том, что молчание является врагом успеха в Центральной Азии. США должны конфигурировать информационную среду публичностью и открытостью относительно своих стратегических целей и путей их достижения (с очевидной осторожностью по вопросам безопасности операций и защиты сил). Такой подход есть нечто большее, чем пассивная прозрачность, которая уже существует, и должен включать активное, воодушевленное публичное представление стратегии лидерами высшего уровня и посредством публичных дипломатических платформ. Молчание, даже в полностью прозрачной среде, порождает теории конспирации и отрицательную пропаганду. И в соответствии с предыдущим выводом, основными стратегическими коммуникационными посредниками стратегии США должны быть сами правительства при необходимой помощи американских экспертов и материальной поддержке в случае необходимости.

Далее, массированное, открытое военное присутствие США будет контрапродуктивным в Центральной Азии. Несмотря на часто героические усилия отделов по связям с общественностью и реальную и существенную гуманитарную работу, проводимую солдатами США в регионе, остается непреложным фактом то, что военные являются громоотводом для критики и теорий заговора, даже и в открытой и публичной среде, упомянутой выше. Это означает, что Транзитный центр-во всяком случае при его нынешней конфигурации,-должен быть закрыт, и следующие, переименованные и с новыми задачами структуры не должны включать участие военных. Сотрудничество в области безопасности при этом варианте не требует це- 
лодневного, полупостоянного военного присутствия США (а если таковое понадобится, ТЦМАМ неудобно расположен для поддержки операций в Ферганской долине).

И последнее, усилия США по оказанию помощи последние десять лет были в общем виде не сфокусированными, разрозненными и в целом неэффективными. Это особенно верно для курированных военными программ по сотрудничеству в области безопасности, которые в общем следовали устаревшему подходу, не соответствующему текущим реалиям в регионе. Так же обстоят дела и со многими программами по развитию, управлению и публичной дипломатии. Причина, по крайней мере частично, в отсутствии стратегического подхода.

С точки зрения сотрудничества по безопасности, некоторые подходы были эффективны в программе защиты стратегического центра тяжести, Ферганской долины. Конкретно, те программы и виды деятельности, что сосредотачивались на прямой поддержке, такие как подготовка и оборудование контртеррористических подразделений, принесли ощутимые результаты, измеряемые в количестве успешных операций против клеток вооруженных экстремистов. Программы пограничной безопасности имели успех даже и при частичной реализации. Финансированная военными гуманитарная помощь, осуществляемая согласованно с другими программами правительства США, также принесла пользу населению. Программы помощи при бедствиях и авариях не являются источником противоречий, а являются ответом на реальные и существенные проблемы, стимулируют позитивные отношения с населением, и заполняют пробелы, оставленные без внимания другими элементами присутствия США в регионе.

К сожалению, эти подходы имели успех не благодаря военной стратегии США на этом театре действий, но вопреки ей. Вместо того, чтобы расширять эти успешные мероприятия, нынешняя стратегия стремится их минимизировать, и даже в некоторых случаях запретить. Большая часть времени и усилий тратится на непродуктивные устаревшие программы. Основной схемой поддержки Соединенными Штатами военных в Центральной Азии является продвижение «широкомасштабной» реформы в обороне, с прицелом на близкое сотрудничество с НАТО. Встречи, посвященные разработке стратегии развития в регионе, изобилуют множеством клише 1990-ых, таких, как «реформа в обороне», «строительство институтов обороны», «развитие сержантского состава», «планирование, программирование, бюджетирование и применение», и конечно, «военный профессионализм». Эти программы не лишены полностью какой бы то ни было ценности и на самом деле с большим успехом применялись в Восточной Европе. Но они неадекватны, неподходящи и даже контрапродуктивны в стратегической среде пост-2014 Центральной Азии. При двухсторонних разговорах как на высшем, так и на рабочем уровне, атмосфера часто становится сюрреалистичной, когда военные и гражданские лидеры подчеркивают современные и будущие угрозы безопасности в Ферганской долине, а лидеры США отвечают им банальностями, которые были актуальными до 2001 года. 
К тому же, корпоративный подход США к сотрудничеству по безопасности был ограничен узким фокусом на министерства обороны партнеров, пренебрегая другими военными формированиями, играющими гораздо более важную антитеррористическую роль. Это ошибочное и близорукое «зеркальное отражение», в котором Министерство обороны США желает иметь дело только со своим точным аналогом в оборонной организации стран Центральной Азии, приводило к дальнейшему ошибочному выделению ресурсов министерствам обороны для которых борьба с терроризмом не является основным приоритетом и которые в Центральной Азии имеют основную задачу защищать государство от внешних угроз (не такие уж и существенные в современной среде безопасности). Успешное военное сотрудничество и помощь требуют работы напрямую и в основном с теми формированиями, чья основная миссия элиминирование угрозы вооруженного экстремизма в Ферганской долине. Все остальное пустая трата ресурсов и усилий.

После 2014, США должны расширить программы успешного сотрудничества в сфере безопасности, развития и публичной дипломатии, в то время как от неуспешных, неэффективных и контрапродуктивных устаревших программ надо отказаться. Военный компонент сотрудничества по безопасности должен быть меньше, но должен быть сфокусирован на создание потенциалов, необходимых для стабилизации и обеспечения безопасности Ферганской долины; безопасность границ и пресечение набегов в долину повстанцев из Афганистана; антитерроризм (сфокусированный на те формирования, которые воюют с повстанцами в и около Ферганы); борьба с наркотиками, чтобы лишить источников финансирования вооруженных экстремистских организаций; помощь при бедствиях и авариях. Все эти линии приложения усилий имели успех в регионе, но часто ресурсы отклоняются из-за ошибочного фокуса нынешних программ на столицы. Прекращение устаревших программ освободит более чем достаточно финансовых и человеческих ресурсов для реализации Варианта 3.

Вариант 3 освобождает дипломатов от необходимости постоянно договариваться о присутствии США и доступе к региону. Он произведет желаемое США стратегическое состояние - стабильная Ферганская долина, что является долгосрочной целью и для каждого государства региона, также как и для России (в отличии от нынешних оперативных целей). Он потребует меньшего общего количества ресурсов чем Вариант 2 - статус-кво (но больше, чем Вариант 1, или «полный вывод»). Однако, и при меньших ресурсах, стратегический эффект возрастет благодаря сфокусированным усилиям.

Вариант 3 увеличит вероятность того, что ИДУ и другие вооруженные экстремистские группы начнут активно саботировать интересы США, когда политика США займется ими напрямую. Этот вариант содержит наибольший риск для США людских потерь, военных и гражданских, с уходом программ США из городских территорий в Ферганскую долину. До сих пор, экстремистские группы в Центральной Азии напрямую не нападали на американские военные сооружения или личный состав, несмотря на наличие больших, резонансных и относительно незащищенных целей в Узбекистане и Киргизкой республике с 2001. Это почти наверняка не явля- 
ется вопросом боевых способностей, так как мишенью ИДУ были другие объекты США, включая правительственные офисы США по всей Центральной Азии, наиболее заметный из которых посольство США в Ташкенте в 2004. ИДУ и напрямую нацеливалось на правительственные объекты всех трех принимающих стран. Более вероятно экстремистские группы, базированные в Ферганской долине, направлены на установление контроля над центром тяжести региона, саму Ферганскую долину. В настоящее время базированные в столице сооружения и направления деятельности США не угрожают напрямую операциям в Фергане. Конечно, в степени в какой они отнимают у США и принимающих наций ресурсы на достижение скрытных, туманных, ориентированных на реформы обороны и обеспечение двухсторонней безопасности упомянутые выше цели, нынешние военные деятельности США действительно помогают этим экстремистским организациям. По иронии, относительно безопасная среда в Центральной Азии в которой военные США действовали с 2001 является свидетельством неэффективности нынешней стратегии. Это измениться в Варианте 3. Когда военные инструкторы США, направленные в Ферганскую долину, начнут работать напрямую с антитеррористическими подразделениями в Центральной Азии, они начнут срывать операции вооруженных экстремистских групп и вероятно превратятся в их мишень. Однако, этот риск может быть смягчен применением разумных мер защиты сил, какие обычно используются в местах с существующими подобными опасностями.

\section{Рекомендации}

Ясно, что Вариант 3 предлагает наилучшую перспективу для политики США в Центральной Азии, усиливая эффект уроков последних десяти лет на формирование региональной стратегии. Стабилизация Ферганской долины (и таким образом и всей Центральной Азии) требует, чтобы политика США и последующие усилия по применению были сфокусированы на Ферганскую долину. Критически важным является и то, чтобы население Центральной Азии понимало, что интересы и политика США в регионе имеют стратегический характер - т.е. имеет цели, выходящие за краткосрочные оперативные соображения военной интервенции в Афганистане. Это означает отказ от артефактов краткосрочной, сфокусированной на оперативных задачах политики, на которую государства Центральной Азии и региональные силы смотрят с подозрением и раздражением. Это освободит ресурсы (дипломатические, военные и экономические) для действий, сосредоточенных на саму Ферганскую долину, вместо нынешних, направленных на города, действий на развитие, дипломатию и сотрудничество по безопасности.

Первым шагом должно быть устранение комплексного военного присутствия, сразу как только это позволят операции в Афганистане (это можно начинать незамедлительно, так как вывод войск уже начался). Ничто не символизирует оперативный подход ярче, чем Транзитный центр в международном аэропорту Манаса, и его закрытие возвестит новый стратегический подход. Имея ввиду упавшие цены и существование перворазрядного сооружения, искушение сохранить ТЦМАМ как платформу для сотрудничества по безопасности будет сильным. Надо избежать этого искушения. У Транзитного центра была конкретная цель, которая не будет 
востребована (или востребована в меньшей степени) после 2014. И что более важно, он расположен рядом с Бишкеком, далеко от Ферганской долины, что неудобно для поддержки базированной на Фергане стратегии. В связи с этим, хотя и Северная Распределительная Сеть (СРС) далеко не настолько спорная как ТЦМАМ, она тоже является артефактом старого подхода, и ее полезность для населения Центральной Азии сильно преувеличена. США следовало бы снижать значение и влияние СРС.

Следующее, все дипломатические, экономические и военные усилия должны быть перенаправлены на поддержку комплексной региональной стратегии, которая сфокусирована на стабильность в Ферганской долине. Эта стратегия должна сделать все необходимое для того, чтобы попытаться включить Россию, Китай и региональные организации с полным пониманием маловероятности их присоединения. Опасения «расширения» влиянии Росси или Китая ошибочны. Во первых, «влияние» не «большая игра» с нулевой суммой. Во вторых, политическое и социальное влияние России в регионе уже значительно, так же как экономическое влияние Китая. Сотрудничество с США может даже понизить уровень влияния России и Китая на этот регион.

Вариант 3 облегчает максимальное применение всех элементов национальной мощи, притом в оптимальных пропорциях. Его сфокусированный подход позволяет применение более эффективной стратегии с меньшими расходами ресурсов, по сравнению с тем, что уже были позиционированы в регионе. Поскольку он сконцентрирован на нестабильность в Ферганской долине, этот вариант содержит наибольший краткосрочный риск для личного состава и объектов США. Однако, это единственный вариант, который напрямую и адекватно учитывает стратегические интересы США в Центральной Азии.

\section{Заключение}

В дополнении к его оперативному значению для военных усилий Коалиции в Афганистане, регион Центральной Азии стратегически важен сам по себе и является критическим для обеспечения успеха в Афганистане после вывода войск. Неспособность рассматривать ГЦА через линзу более широких стратегических интересов подвергает риску успех в Афганистане после вывода, вредна для региональной безопасности и увеличивает вероятность того, что США будут опять втянуты в конфликт на гораздо менее благоприятных условиях. 


\section{Литература}

Declaration by the Heads of the Member States of the SCO In SCO Annual Summit, Astana, Kazakhstan. Shanghai Cooperation Organization, 2005.

Gladstone, Rick. "Kyrgyzstan Sees Instability at End of Afghan Mission." New York Times (2009).

Kucera, Joshua. "Why Russia Fears U.S. Afghan Plan." The Diplomat (2011).

Lisbon Summit Declaration Issued by the Heads of State and Government in the meeting of the North Atlantic Council. NATO Public Diplomacy Division, Press Release 155, 2010.

Mattis, James N.. U.S. Central Command Posture Statement., 2011.

U.S. Department of State, Office of the Coordinator for Counterterrorism, Country Reports on Terrorism 2010 . Washington, D.C.: State Department, 2011.

Weitz, Richard. "Storm Clouds over Central Asia: Revival of the Islamic Movement of Uzbekistan (IMU)?" Studies in Conflict and Terrorism 27, no. 66 (2004): 507. 